\title{
On the Problems Arising during the Transformation of the English Verbal Phraseological Units
}

\author{
Mehin Suerek ${ }^{1}$ \\ ${ }^{1}$ Department of English Grammar, Azerbaijan University of Languages, Baku, Azerbaijan \\ Correspondence: Mehin Suerek, Department of English Grammar, Azerbaijan University of Languages, Baku, \\ Azerbaijan. E-mail: mehin.suerek@gmail.com
}

$\begin{array}{lr}\text { Received: May 11,2014 Accepted: October 20, } 2014 \quad \text { Online Published: November 25, } 2014 \\ \text { doi:10.5539/ijel.v4n6p151 } & \text { URL: http://dx.doi.org/10.5539/ijel.v4n6p151 }\end{array}$

\begin{abstract}
The process of globalization, covering various spheres of life, is universal, as for thousands of years separated, remote to some extent, differential events - national or regional peculiarities, habits, complexes strongly influenced by modern technologies, approaching each other with incredible speed and combine as a result of multifaceted economic, socio-political, moral and ideological ties, limiting the kind of peculiarities, lead to the events and processes happening in the world.

Today a rapid growth of the prestige of the English language is observed in the modern world, as well as in Azerbaijan and this can be explained by, at least, two reasons. The first: there exists a necessity for a universal means of communication, a common language for the whole mankind. The second: the advantages of the English language in comparison with other international languages in gratifying this need.

It is not a secret that in our days the English language is one of the most important languages in the process of intercultural communication. We may say that English is a Global Language today as from the geographical point of view it is spread throughout the world among the territories of three big oceans: the Atlantic, the Pacific and the Indian Oceans, and from the social-cultural point of view almost all the population of the Earth use this language in different purposes.

The article represented to your attention is devoted to the problems arising during the transformation of the English verbal phraseological units. In this investigation different linguistic methods such as descriptive, transformational, comparative-typological were used.
\end{abstract}

Keywords: language, culture, intercultural dialogue, verbal phraseological units

\section{Introduction}

Today intercultural communication is an inseparable part in the life of the progressive mankind. Every on culture dialogue has taken a new meaning in the context of globalization and current international climate in politics. Thus it is becoming a vital meaning of maintaining peace and world unity.

In present-day life taking the process of globalization into consideration we have been educated apart ona another had few opportunities to meet and learn to trust one another. Some people have seen this as a significant obstacle to community peace and reconciliation in the world.

It is not a secret for anybody that today there is a great need for foreign language education. Increasing globalization has created a large need for people in the workforce who can communicate in multiple languages.

A rapid growth of the prestige of the English language is observed in the modern world, as well as in Azerbaijan and this can be explained by, at least, two reasons. The first: there exists a necessity for a universal means of communication, a common language for the whole mankind. The second: the advantages of the English language in comparison with other international languages are given advantages in gratifying this need.

Learning foreign languages gives the learners possibilities to go in touch with the people, culture and traditions of other countries and helps them to understand their own language and culture. Language is the means of the forming, developing and keeping values of of the culture. Language and culture are closely interrelated. Culture is the foundation of communication. Cultures provide people with ways of thinking, seeing, hearing and 
interpreting the world. Thus, the study of cross-cultural communication is fast becoming a global research area. As a result cultural differences in the study of cross-cultural communication can already be found.

In modern multicultural society crosscultural dialogue is not a conversation between two cultures, but a close interaction between them. Intercultural dialogue is the communication between the representatives of the various cultures from different countries.

It is an undebatable fact that the close connection and the interaction of the languages influenced on the ways of the expression of the borrowings, also phraseological borrowings. Mutual influence among the world languages and the borrowings - from one language int another one-all these processes have happened very often. So, it gives the reason to analyze all these processes.

Languages are the most powerful instruments of preserving and developing our tangible and intangible heritage. All moves to promote the dissemination of mother tongues which will serve not only to encourage linguistic diversity and multilingual education but also to develop fuller awareness of linguistic and cultural traditions throughout the world and to inspire solidarity based on understanding, tolerance and dialogue.

It is not a secret that in our days the English language is one of the most important languages in the process of intercultural communication. We may say that English is a Global Language today as from the geographical point of view it is spread throughout the world among the territories of three big oceans: the Atlantic, the Pacific and the Indian Oceans, and from the social-cultural point of view almost all the population of the Earth use this language in different purposes.

Conversation is the study of speech in situations of everyday life. Conversation analysis generally attempts to describe the orderliness, structure and sequential patterns of interaction.

Culture and communication are inseparable because culture not only dictates who talks to whom, about what, and how the communication proceeds, it also helps to determine how people encode messages, the meanings they have for messages, and the conditions and circumstances under which various messages may or may not be sent, noticed, or interpreted. Culture is the foundation of communication.

\section{Material Studied}

But what culture actually is? There are numerous definitions of culture. As to Mike Wills: "Culture is a thin, but very important veneer that you must be careful not to scratch. People from different cultures are basically the same and respond in the same way. However, you make sure that you understand their basic customs and show an interest and willingness to learn the differences between your cultures".

While E. Schein told: "Culture is the way in which a group of people solve problems and reconcile dilemmas".

As to Clifford Geertz's opinion: "Culture is the fabric of meaning in terms of which human beings interpret their experience and guide their action". Culture basically affects and influences our way of communicating with one another because culture and communication are interdependent. The way we act and the things we determine the culture we belong to and on the other hand culture determines how we act and communicate. As Geertz puts it; every specific act, every utterance, every thought must be understood within a much larger, much broader context. Cultural awareness is therefore apparent.

IngerAskehave had interpretive approach: "An understanding of effective intercultural communication is relevant since many cultural groups around the world have different patterns of behavior, belief, values and norms which can create communication barriers".

People must possess a certain level of global competence to understand the world they live in and how they fit this world. This level of global competence starts at a ground level — the university and its faculty with how they generate and transmit cross-cultural knowledge and information to people. The core of cross-cultural communication is to establish and understand how people from different cultures communicate with one another.

Effective communication with people of different cultures is especially challenging. Cultures provide people with ways of thinking, seeing, hearing and interpreting the world. Thus the same words can mean different things to people from various cultures, even when they talk the same language. When the languages are different and translation has to be used to communicate, the potential for liguedation of misunderstanding . The study of cross-cultural communication is a fast becoming global research area. As a result cultural differences in the study of cross-cultural communication can already be found.

Culture must be fully incorporated as a vital component of language learning. Second language teachers should identify key cultural items in every aspect of the language that they teach. Foreign language learners can be successful in speaking a second language only if cultural issues are an inherent part of the curriculum. 
Language and culture are so intricately related that their boundaries, if any, are extremely blurred and it is difficult to become aware of the assumptions and the assumptions and expectations that we hold. It should be reiterated that language teaching is culture teaching. Language and culture go hand in hand.

Many scientists have attempted to show that language and culture are from the start inseparably connected. The reasons why this should be the case are: language acquisition does not follow a universal sequence, but differs across cultures; the process of becoming a competent member of society is realized through exchanges of language in particular social situations.

As it is well-known language is a means of forming and storing ideas as reflections of reality and exchanging them in the process of human intercourse. Undoubtedly, language is social by nature not only as it is inseparably connected with the people who are its creators and users, but also, we must mention that it grows and develops together with the development of society. It is natural that depending on different circumstances each language has its own development.

It is necessary to mention that mutual connections of the different languages and their mutual influence on the historical development of the peoples during all periods were not the same. Only as the consequence of the mutual relations one language borrows lexical, phonetic and morphological features from another one. Vocabulary of any language is enriched by all these borrowing features and it is developed by means of cooperation of countries.

That is why the world's cultural wealth is its variety in dialogue. While each culture draws from its own roots, it must not fail to blossom when crossing other cultures.

Among UNESCO's chief missions is to ensure space for and freedom of expression to all the world's cultures. Therefore, it isn't a matter of identifying and safeguarding every culture in isolation, but rather of revitalizing them in order to avoid segregation and cultural entrenchment and prevent conflict.

Every cultural dialogue has taken a new meaning in the context of globalization and current international climate in politics. Thus, it is becoming a vital meaning of maintaining peace and world unity.

When we look carefully at the nature of human language and the mental activities that must take place when we speak or listen to speech, we become aware of the complexity of the processes involved. As we describe the activities involved in language, bear in mind the sorts of things a machine or computer program would have to "know" to deal efficiently and appropriately with ordinary human discourse.

On the surface, languages such as Chinese and Turkish seem quite different from each-other. They sound different, seem to have different grammatical rules, and, to a native English speaker, may not even sound like languages at all. The stream of speech coming from someone speaking a totally unfamiliar language sometimes sounds like a continuous rush of gibberish rather than separate words.

However, beneath the surface differences all natural human languages (languages that arose naturally in human society as contrasted with artificially constructed ones such as computer programming languages) share some fundamental properties. The most important of these is productivity. Natural languages are productive in two senses.

First, in every human language there is no upper limit to the number of novel sentences that can be created. The capacity of hundreds of thousands of words and complex grammatical rules to generate an infinite number of different sentences should not be surprising. Just consider the possibilities we have for composing new melodies and musical compositions from the few notes of the ordinary musical scale.

The second way in which all languages are productive is that the same ideas or thoughts can be expressed in any language. What can be said in English can also be said in French, in Azerbaijani or in Russian. Of course, if a language doesn't have a word for a particular concept, then several words may be needed to express the concept.

Naturally, the role of language in translation is just the same which has always performed "the most important means of human communication".

As it is known, translation skills are perfected every year and that translation is of great importance as it's closely connected with cultural life, customs and habits, history of many nationalities all over the world and through it people get to know one another and aquaint the other nations with their own cultures. Deep are the roots of translation work of each nation and propositions of its essense and problems are known from ancient times. In these propositions attempts to define the role of translation in social life, in native culture and too many other features are reflected in details. But the concept "translation" refers to our century for it came to an existence in 1920. Every year translational skills are getting more and more improved. First it was applied only 
to the field of belles-lettres style. But the position of translation has been greatly changed at the beginning of 1950 when linguistics got interested and further more indulged in it.

It is necesarry to remark that the term "theory of translation" became more visible not only in literary works but in system of language sciences as well. Consequently, together with belles lettres translation of other kinds of translation activity and practice appearing in those days which were in the process of development of simultaneous interpreting refering to the middle of 1930 when it became an independent science. The great demands are laid on the work of translator. Above all a translator would possess versatile knowledge. Lack of knowledge, for instance, leads to misunderstanding in translation or it may decolourise the translation depriving it of its national peculiarities. This mistake can also lead to great errors, creating false imagination of the country and its people. Translator should possess general knowledge in general linguistics because many problems found in translation can only be solved on the basis of philology. Therefore, translator should have a good command in both languages.

The theory of translation represents not a special collection of prescriptions. There can be some instances that require the translator to keep to an individual approach. It's a fact that translation generally recognized as correct and reasonable in prose, may be not suitable, for example, with respect to fiction.

As it is evident, the translation of scientific technical literature is characterised by using exact and monosemantic terms. It means that the translator ought to know the terminology in the field given as definite.

As for emotional colouring, for instance, it's missing in scientific and technical texts. In translation of official papers the interpreter will get in touch with analogical tasks.

Thus, the theory of translation turned into complex and ramifing scientific discipline and the necessity to determine its common, starting and basic position became compulsory.

Translation is one of the components of intercultural dialogue. BA and MA programs on translation offer a special course on "Country studies and intercultural dialogue". Written translation gives a broader access to different information sources, thus pursuing intercultural dialogues. Events promoting intercultural dialogue is an essential part of learner's campus life. This is especially important when the higher education becomes more globalized and internationalized. The students of foreign languages department make celebrations of many religious and national holidays of the country they study, such as Christmas, Halloweens day, etc. In their turn foreign students are active participants of celebrations of Novruz and other Azerbaijani national holidays. In this way we demonstrate mutual tolerance and respect to each other's religious and national heritages.

During our investigation about how the translation may be implemented in social life, we come to the following conclusions: 1. from one language into another non-kindred languages closely related; 2 . from one literaly language into its dialect or vice-versa; 3 . from the ancient form of language into the present state of the same language.

In translation we have always had two texts. The first is the original text which is created irrespective of the other, the second text is created on the basis of the first with the help of certain operations-interlinguistic transformations. The first text is called the text of the original, the second - the text of translation. The language in which the original text is written is called the source language (SL), the language into which the translation is done is called the target language (TL).

Speaking about culture through idioms, phraseological word combinations, set expressions and proverbs, we must mention that phraseology is a fuzzy part of language. It embraces the conventional rather than the productive or rule-governed side of language, involving various kinds of composite unit and idioms, fixed phrases and collocations. Phraseological units or idioms, as they are called by most western scholars, represent what can probably be described as the most picturesque, colourful and expressive part of the language's vocabulary.

Analyzing the idioms of English, Azerbaijani and Russian peoples, we came to the conclusion that their material moral values are alike. There are several examples illustrating these investigations. For example:

A load fell from one's shoulders (mind, chest). / A weight seems to roll off someone's back. / As if a mountain fell from one's shoulders. - Üstündən ağır bir daş götürüldü! - Камень от сердца отвалился. / От души отлегло. / Словно гора с плеч свалилась.

Cut your coat according to your cloth. / Stretch your legs according to your coverlet. / Cf. Put your hand no further than your sleeve will reach. - Ayağını yorğanına görə uzat. - Протягивай ножки по одёжке.

Enough is as good as feast. - Xımır-xımır - həmişə. / Kifayət də bərəkətdir. / Bolluğa şıltaq atma. / Az olsun həmişə olsun. - Хорошенького - понемножечку. 
A bad workman finds fault (quarrels) with his tools. (in the meaning of "Who cannot dance finds different causes / reasons") - Oynamaq bilməyən gəlinə oyun yeri dar gələr. - Плохому танцору и штаны мешают. / Плохому танцору одежда мешает. / Ср. У плохого мастера всегда инструмент виноват. / Мастер глуп - нож туп.

Better one-eyed than stone-bind. / Among the blind the one-eyed is king. / In the land of the blind the one-eyed is king. / In the realm of the blind the one-eyed is king. / Half a loaf is better than no bread. / A bit in the morning is better than nothing all day. / There's a small choice in rotten apples. / Any port in a storm. -Qazan olmayan yerdə, güvəc də qazandır. - Лучше кривой, чем слепой. / Кривой -неслепой, межслепыхикривойзрячий. / Набезрыбьеирак - рыба.

On the one hand those proverbs express uncertainty, but on the other hand all express the sober common sense of economy.

The other example: A bargain is a bargain. / Be slow to promise and quick to perform. / Promise is debt. / If you pledge, don’t hedge. / A promise is a promise. - Sözləşmə puldan bahadır. / Söhbət danışıqdan keçər. - Уговор дороже денег. / Если не удержался от обещаний, следует быть верным своему слову.

Be slow to promise and quick to perform. / Cf. Promise is debt. / If you pledge, don't hedge. / A promise is a promise. - Söz vermə, verdin - üstündə dur. - Недавшислова - крепись, адавши - держись./Давшислово, держись, анедавши, крепись.

Deeds no words. /Action speaks louder than words. - Sözlə yox, işlə göstər. - Дела говорят громче, чем слова. (5) Those proverbs mean that an honest man has to be a man of word.

When we speak about the transnational processes and especially the transformation of the phraseological units from English into German or Russian or Azerbaijani and vice-versa, we must touch upon the lexico-phraseological problems of translation. We know that every language differs not only by its own grammatical structure, but also by its semantic structure. By the semantic structure of the language we mean the field of meaningful units, i.e. words, word combinations, set-phrases to which certain meanings are referred in the dictionaries. Depending on different circumstances each language has its own development, so it is with semantic aspect of all languages. The semantic structure of the language has a direct reference to translation, for the plane of content as the basis of equivalency depends mostly on the semantic structure of the separately taken words. The thing is that not in all cases we find dictionary correspondences for all the words. There are cases that a word of the SL corresponds to a word of the TL in one meaning, but does not correspond in other meanings. For example the Russian word “жертва" or the Azerbaijani word "şəhid” corresponds to the English word "victim" in the meaning of "человек, пострадавший или погибший от чего-либо", or "həуatını fəda edən”, but in the meaning of “приносимое в дар божеству предметы или существа или добровольный отказ от чего-либо”, or in Azerbaijani "Allah yolunda qurban kəsmək və ya bir şeydən könüllü imtina etmək” it corresponds to the English "sacrifice".

The choice of equivalents for each word becomes more difficult when we begin to deal with polysemantic words, that is one graphical sign corresponds to several referents or meanings. The solution of this problem is connected with context and situation. By context we mean the language environment in which the given language unit is used. By the language environment we mean all the words, grammatical constructions and forms that are related to the given word. Word is not the only language unit that is used in certain language environment. The same can be said about all the language units as well. Contexts may be narrow (microcontext) and broad (macrocontext).

By the narrow context we mean the context of a sentence, i.e. the language units that form the environment of the given word within the boundaries of the sentence. By the broad context we mean the language environment which is beyond the boundaries of the sentence, it is textual context, i.e. the sum of language units that surround the given unit beyond the boundaries of the sentence. It is impossible to define the exact boundaries of the broad context; it may consist of a group of sentences, a paragraph, a chapter or a whole story or novel.

The narrow context in its turn may be divided into syntactic and lexical. By syntactic context we understand the syntactic construction in which the given word, word combination or clause is used. By lexical context we mean the sum of concrete lexical units, words and set-phrases that surround the given language unit.

Every language has a great deal of idioms, phraseological word combinations, set-expressions.Different problems, such as: lexico-grammatic, stylistic, phraseological are arising during the transformation of these units.

Analyzing the phraseological problems of translation we also take into consideration the main sources of formation of the phraseological word-combinations in the modern English language at the end of the XX - the beginning of the XXI centuries. 
The main sources of formation of the phraseological word-combinations in the modern English language are: sphere of notions, spiritual culture, sphere of working activity of a man, historical facts, folklore. It is necessary to mark that the reasons of appearance of new words and new meanings of old words, mainly, are formed by means of changes in social life, in the development of industry and other spheres of man activity, and also in the development of thinking.

Phraseological units, formed in the sphere of living notions, are made 33\% per cent of general amount of investigated phraseological word combinations, which are formed by means of an influence of external factors. They are steady set-phrases, which reflect in the ordinary sense of the word - straightly or indirectly the real facts of everyday life of England, characteristic for the country events, facts of reality, specific features of social relations that have been present at the end of the XX and in the beginning of the XXI century.

Every language has vivid examples, expressions that express the notions - actual for the life of society in the definite historical period. Historical actual events throughout the world give a foundation for the development of the meanings of set-expressions. Characteristic examples are: a land-office business, a dormant account, straight A, the Black Belt, back bench, even bet, to give somebody the benefit of the doubt, make the best of both words, kill the bill, omnibus bill, a true bill, campaign biography, member's bill, public bill, principal boy, stand in the breach, a stand still agreement, aid and abet, a fighting chance. Some phraseological units are indebted with their appearance to some historical facts. For example: a cat o'nine tails, from China to Peru, the city of Angels, the city of Brotherly Love, the city of Magnificent Distances, the city of the Notions, the city of the One Hundred Hills, the city of the Saints, the city of the Seven Hills, the city of the Falls, the Crescent City, the Empire City, the Eternal City, the Federal City, the Golden City, the Windy City, Kangaroo closure.

In our days translation activity obtained unprecedented scope thanks to the increased international contacts. The right choice of the word for a complete transformation of the meaning of the word in the text is one of the complicated objectives in the translation process. The difficulty of this task is conditioned by the complex nature of the word and its versitile and semantic value. The word as a lexical unit in Azerbaijani and Turkish, English and German, Italian and French, Arabic and Russian languages don't always coincide. Too often one word in the Azerbaijani or Russian may correspond a composite word or a whole word combination of English. Analyzing the idioms of English, Azerbaijani and Russian peoples, we came to conclusion that their material-moral values are alike. There are several examples illustrated these investigations. For example:

“Acizi vurmazlar. - Don't hit a man when he's down. - Лежачего не бьют”. Or

“Adamın sözü doğru olanda q1lınc kimi daşdan keçər. - Truth has thorns. / Truths and roses have thorns about them. / Home truths are hard to swallow. / Home truths are usually unpalatable. / Nothing stings like the truth. Правда двенадцать цепей разорвёт. / Прямое слово рожном торчит. / Правда всегда перетянет".

Many more examples can corroborate the conclusion that different peoples have alike material-moral values. Thus, if we learn not only foreign languages, but also versatile foreign cultures, we can better understand each other and this tendency will come to common understanding and mutual respect among peoples throughout the world.

One of the main source of formation of the phraseological word combinations of the end of the XX -at the beginning of the XXI century is a sphere of professional activity of man. All kinds of human activity have their own vocabulary, special terms, and they get into literary language. Here belong commercial, juridical, parliamentary, stock, diplomatic, sea, aviation, technical, financial, economic terminology. For example: milk and water, an easy mind, conscience money, Oxford mixture, suck the money, money talks, a Mother Hubbard, the observed of all observers, to be off one's oats, conscientious objectors.

The other of the main sources of formation of the phraseological word combinations is recomprehendation of the expressions, which originally are used in different kinds of sport, hunting, in some rules of chess and cards, that are wide spread in casinos, gambling houses, at magnificient hotels throughout the world in XX - XXI centuries. For example: to be in at the death, to be on the cards, the best card, a big card, cards on the table, to have the cards; lucky in cards, unlucky in love; even the score, set off at score, know the score, pay off a score, to buy money.

Investigating the main sources of formation of the phraseological word combinations in the modern English language at end of the XX - the beginning of the XXI century, the most principal extralinguistic spheres of formation of the largest part of the phraseological block (frame) of the literary language were revealed. Analysis of the phraseological units clearly show the dependence of the development of the phraseology from the surroundings, environment, reality, material and spiritual life of the people. 
By "the phraseological problems of translation" we mean the following forms and methods of translation of the proverbs, sayings, catch words, familiar quotations, briefly speaking, all kinds of the phraseological units.

As it is well-known, that "equivalent, analogue, descriptive translation, antonymic translation, calque or loan translation, combined translation" are the forms and methods of translation which are used to convey the meanings of set-phrases.

Phraseological units are set-expressions, figurative set-expressions described as "idioms". Such units have an important role to play in human communication. They produce a considerable expressive effect, because they affect the reader's emotion his aesthetic perception, his literary and his cultural association. Whenever the author of the source text uses an idiom it is the translator's duty to try and reproduce it with the utmost fidelity.

The idiom's semantics is a complex entity and there are five aspects of its meaning. These aspects will influence the translator's choice to find an equivalent in the target language. They are: a) the idiom's figurative meaning; $b$ ) its literal sense; c) its emotive character; d) stylistic register; e) national coloring.

However, the figurative meaning is the basic element of the idiom's semantics. For instance, "red tape" means "bureaucracy", "to kick the bucket" means "to die", "to wash dirty linen in public" may be understood as "to disclose one's family troubles to outsiders".

Idioms can be positive, negative or neutral. It's clear that "to kill two birds with one stone" means in Azerbaijani "bir güllə ilə iki dovşan vurmaq" və ya "bir oxla iki dovşan vurmaq", in Russian "убитьдвухзайцеводнимударом" is a good and right decision; "to find a mare's nest" means in Azerbaijani "yersiz söz demək, mənasız danışmaq", in Russian "попастьпальцемвнебо, попастьвпросак" is "ludicrous mistake", while "Rome was not built in a day" means in Azerbaijani "Roma bir gündə qurulmamışdır", in Russian "Римстроилсяневодиндень" is a simple and neutral statement of the fact.

Besides mentioned above, an idiom can be nationally colored and include some words which mark it as the product of a certain nation. For instance, "to set the Thames on fire" means "qeyri-adi bir hərəkət etmək" "достатьлунуснеба", т.е. "сделатьчто-либонеобычное, изрядавонвыходящее" and "to carry coal to Newcastle" means "Nyukasla kömür aparmaq" - "возитьугольвНьюкасл”, т.е. "возитьчто-либотуда, где этого итак достаточно" are undoubtedly British.

But "to discover America" means "Amerika kəşf etmək, yəni çoxdan hamıya məlum olan şeyi elan etmək" “открыть Америку,т.е. говорить о том, что всем давно известно” is, of course, the American idiom.

Another example, "Avazın xoş gəlir, oxuduğun Quran olsa" means in English "to make a fool of someone" “свежо предание, а верится с большим трудом, поёт куролесу (греч. «Господи, помилуй»), а несёт аллилуйю"; "Araz aşı̆̆ındandır Kür topuğundan" means that "one can wade through any sea, someone is a devil-may-care fellow, not to give a damn, someone is a mad-brain", in Russian "Араз по щиколотку, Кура по лодыжку, море по колено, т.е. кому-либо всё до лампочки, безразлично”; “Araza susuz aparıb susuz gətirər" means "to be a cunning, sly, ingenious, a crafty man" - “лис, т.е. очень хитрый человек" are naturally, the Azerbaijani phraseological units.

Sometimes the complex character of the idiom's semantics makes its translation no easy matter. There are also some other factors which complicate the task of identification, understanding and translation of idioms.

Firstly, an idiom can't be mixed up with a free-word combination, especially if its literal sense is not exotic. For example, "to have butterflies in one's stomach", and rather trivial "to measure one's length" that means "bir kəsin boyunu ölçmək".

Secondly, an idiom of source language may be identical in form to a target language idiom, but have a different figurative meaning. Thus, the English "to lead someone by the nose" implies a total domination of one person by the other Russian "вестикого-либонаповоду, т.е. держатьвподчинении" and "to stretch one's legs" means in Azerbaijani "havayaçıxmaq", in English "to take a stroll", in Russian "размять ноги, т.е. прогуляться".

Thirdly, source language's idiom can be wrongly interpreted due to its association with a similar target language's unit. For instance, "to pull the devil by the tail", which means "to be in a trouble"may be misunderstood by the translator under the influence of the Russian idiom "бедствовать, сидетьбезгроша" or “битьсякакрыбаоблёд”.

Fourthly, source language's idiom may have a broader range of application than its target language's conterpart identical in form and meaning. For instance, the English "to get out of hand" is equivalent to the Russian "отбитьсяотрук" and Azerbaijani "həddini aşmaq". The latter is often used to translate it. For example: The 
children got out of hand while their parents were away. - Valideynlər olmadığı üçün uşaqlar heç sözə baxmır. В отсутствии родителей дети совсем отбились от рук.

The English idiom can be used whenever someone or something gets out of control, while the Russian idiom has a more restricted usage. For example: What caused the meeting to get out of hand? - Nəyə görə iclasda qarmaqarışılıq yarandı? - Почемусобраниепрошлонетакорганизованно?

Fifthly, it is necessary to mention that some phraseological units have transnational peculiarities. For example: "Nuh əyyamında" - "Nikolayın vaxtında" - "when Queen Anna was alive" mean "in the year dot, in the past times - в давние времена"; "Allah qorusun!" - "Might be lucky!” - “ бог в помощь” mean "something may turn up, the wheel of fortune might turn in our favour"; "Ağrın mənə gəlsin! / Ağrın alım!" - Dear! / Honey! / Darling! - (ласковое обращение в значении, чтобы все недуги перешли на говорящего) “дорогой! / мой милый!” mean "tender appeal to someone”; “Allah ağıl versin!” - "Be clever! / Be a good boy (girl)!” - “дай ему боже ума! / Господи образумь!"

The possibility of misinterpreting an idiom in the source text calls for a great deal of vigilance on the part of the interpreter.

Summing up our investigation, we'd like to emphasize that there are four methods to handle a SL's idiom in the translating process:

1) identical SL's idiom in all aspects, for instance, "to pull someone's chestnuts out of the fire" - "bir kəsə görə özünü oda vurmaq” - “таскатькаштаныизогня”;

2) SL's idiom can be translated to TL's idiom by different image, for instance, "to make hay while the sun shines" - "dəmiri isti-isti döyərlər" - "куй железо пока горячо";

3) SL's idiom can be translated by word-for-word in TL, for instance, "people, who live in a glass houses should not throw stones" - “döymətaxtaqapınıdöyərlərdəçirqapını" - “люди, живущиевстеклянныхдомах, недолжныбросатькамни";

4) instead of translating the SL's idiom, translator may try to explicate its figurative meaning, so as to preserve at least the main element of its semantics, for instance, in Azerbaijani - "Allahsız yerdə otur, böyüksüz yerdə oturma", in English - "an apple-pie order"; in Russian - "шарашкинаконтора".

We must notice that of great interest for translators are the transformation of prolonged metaphors. English authors very often play up with figures of speech creating on their bases a scene where everything is interconnected. In this case translator has two ways to convey the image: either he retains the basic figure of speech or changes it completely and creates his own prolonged imagery in translation.

Naturally, it is better to try to preserve the figures of speech inherent to the original. While doing it, the translator very often is obliged to refuse the usage of the phraseological analogue which might have been possible to use, had not the figure of speech prolonged, but single.

\section{Conclusion}

Analyzing the verbal phraseological units we discover the increasing use of the English language globally, which has had a large impact on many other languages, leading to language shift and even language death, and to claims of linguistic imperialism. English itself has become more open to language shift as multiple regional varieties feed back into the language as a whole.

\section{References}

Blue, G. M. (1993). Language, learning and success: Studying through English. London: Macmillan

Brooks, N.(1975). The Analysis of Foreign and Familiar Cultures. National Textbook Company.

Brown, G. (1990). Cultural Values: The Interpretation of Discourse. Oxford.

Fries, C. H. (1994). Meaning and Linguistic Analysis.

Gudykunst, W. B. (2004). Bridging Differences: Effective Intergroup Communication. Thousand Oaks, London and New Delhi: Sage.

Heyward, M. (2002). From international to intercultural: Redefining the international school for a globalized world. Journal of Research in International Education, 1(1), 9-32. http://dx.doi.org/10.1177/147524090211002

Jackson, W. (2003). Communication Theory. 
Köchler, H. (1978). Cultural Self-Comprehension of Nations. Tübingen: Erdmann.

Kramsch, C., \& Widdowson, H. G. (1998). Language and Culture. Oxford University Press (OUP).

LeBaron, M. (2003). Cross-Cultural Communication. Beyond Intractability.

Lyons, J. (1981). Language, meaning and context. London: Fontana Paperbacks.

Newmark, P. (1988). A textbook of Translation. Prentice Hall International (UK) Ltd,.

Provic, A., \& Denec, I. (1977). Translation as Comparison. Nitro.

Rosie, A. M. (1966). Information and Communication Theory. London: Glasgow.

Savory, T. H. (1968). The Art of Translation. Leningrad.

Veliyeva, N. C. H. (2010). The Great Azerbaijani-English-Russian Dictionary of Idioms. Baku, Azerneshr.

Veliyeva, N. C. H. (2012). The relationship of the language and culture. Unıversıtatea Dın Bucureştı Facultatea De Lımbı Şı Lıteraturı Straıne Asociatia Slavıştılor Dın Romanıa, Departamentul de filologie rusa şi slava, Romanoslavıca, vol.XLVIII, nr.3, Editura Universitaşii din Bucureşti, pp. 215-223.

Veliyeva, N. C. H. (2013). Some Aspects and Peculiarities of Intercultural Communication in the Process of Globalization.

Wohlgemuth, J. (2009). A Typology of verbal borrowings. Berlin: Mouton de Gruyter. http://dx.doi.org/10.1515/9783110219340

Young, K. Y. (1988). Communication and Cross-Cultural Adaptation: An Integrative Theory. Cleve don and Philadelphia: Multilingual Matters.

\section{Copyrights}

Copyright for this article is retained by the author(s), with first publication rights granted to the journal.

This is an open-access article distributed under the terms and conditions of the Creative Commons Attribution license (http://creativecommons.org/licenses/by/3.0/). 